(c) Elsevier/INRA

\title{
Note
}

\section{Mosaicism of $50, \mathrm{XX} / 51, \mathrm{XX}$ in a Murrah buffalo Bubalus bubalis}

\author{
BR Yadav ${ }^{1, *}$, S Kumar ${ }^{1, * *}$, OS Tomer ${ }^{2}$, CR Balakrishnan ${ }^{2}$ \\ 1 National Institute of Animal Genetics, \\ NDRI Campus, Karnal-132001; \\ 2 Dairy Cattle Genetics Division, \\ National Dairy Research Institute, Karnal-132001, India
}

(Received 23 October 1989; accepted 1 July 1991)

Summary - Cytogenetical and gynaecological studies were carried out on an eight year old buffalo with irregular breeding history. The animal had mosaicism of two cell lines $(51, \mathrm{XX}$ in $22.67 \%$ and $50, \mathrm{XX}$ in $67.33 \%)$ with normal reproductive organs and the tract. The extra chromosome was identified as the fifth submetacentric autosome by conventional staining and confirmed with the G-banding technique.

Murrah buffalo / mosaicism / chromosome / autausomal trisomy

Résumé - Mosaïque de 50,XX/51,XX chez un buffle Murrah (Bubalus bubalis). Des études cytogénétiques et gynécologiques ont été réalisées sur une bufflesse de 8 ans ayant eu une carrière reproductive irrégulière. L'animal présentait une mosaïque de 2 lignées cellulaires (51,XX pour 22,67\% et 50,XX pour 67,33\%) avec un tractus et des organes génitaux normaux. Le chromosome supplémentaire a été identifié comme étant le cinquième autosome submétacentrique, par les techniques de coloration classique comme avec le typage en bande $G$.

buffle Murrah / mosaïque / chromosome / trisomie autosomique

* Correspondence and reprints

** Present address : Department of Molecular Genetics, Institute of Animal Physiology and Genetics, Ers, Roslin, Midlothian EH25 9PS Scotland, UK 


\section{INTRODUCTION}

Reproductive disorders, such as repeat breeding, spontaneous abortions, late maturity, anoestrous etc. are major problems in buffalo breeding. During routine screening of such animals in an organized herd an eight year old buffalo with irregular heat cycle was referred to our laboratory for cytogenetical examination. The breeding, history of the animal revealed that she had calved three times and subsequently the animal was bred seven times but did not conceive. The present report deals with the cytogenetical and gynaecological examinations of the above buffalo.

\section{MATERIALS AND METHODS}

Blood was collected from the jugular vein of the animal in sodium heparinized vacutainer tubes for cytogenetical studies. Chromosome preparations were obtained by the usual procedure of short-term whole blood culture as per modifications (Yadav and Balakrishnan, 1985). The G-banding was carried out by the trypsin treatment method (Seabright, 1971). Thorough gynaecological examination was conducted by rectal palpation of the buffalo. None of the close relatives of the buffalo viz dam, sire and progenies were available for the study.

\section{RESULTS AND DISCUSSION}

The examination of Giemsa stained metaphase plates showed presence of mosaicism of two cell lines; one with normal chromosome complement, 50,XX and the other with an extra chromosome, 51,XX (fig 1). The extra chromosome was present in $22.67 \%$ of a total of 75 metaphase plates examined. On the basis of gross morphology, the supernumerary chromosome was identified as the fifth submetacentric autosome (fig 2). Homologies of G-banding patterns (figs 3, 4) confirmed the trisomy of the fifth autosome. The G-banding patterns of fifth pair of autosomes observed in this study were quite comparable to those described in Murrah (Riverine type) buffalo by Gupta and Ray Chaudhuri (1978), Di Berardino and Iannuzzi (1981), Di Berardino et al (1981) and Bongso and Hilmi (1982). The fifth chromosome of the Swamp buffalo also had a similar G-banding pattern (Toll and Halnan, 1976; Miyake et al, 1980; Di Berardino and Innuzzi, 1981; Bongso and Hilmi, 1982).

Cytogenetical examination was carried out only on blood cultures. The gynaecological examination did not reveal any abnormality of the reproductive tract or ovaries.

The authors are not aware of any report of autosomal trisomy in water buffalo; however, in cattle various cases of trisomy or presence of extra chromosomal elements are available. These reports can be delineated in two groups, one associated with abnormalities of a specific system and the other with dwarfism and general growth retardation.

Congenital abnormalities in association with an extra chromosome have included brachygnathia (Herzog and Honn, 1968; Mori et al, 1969; Dunn and Johnson, 1972; Herzog, 1974), cardiac abnormalities and umbilical hernia (Tschudi et al, 1975), 


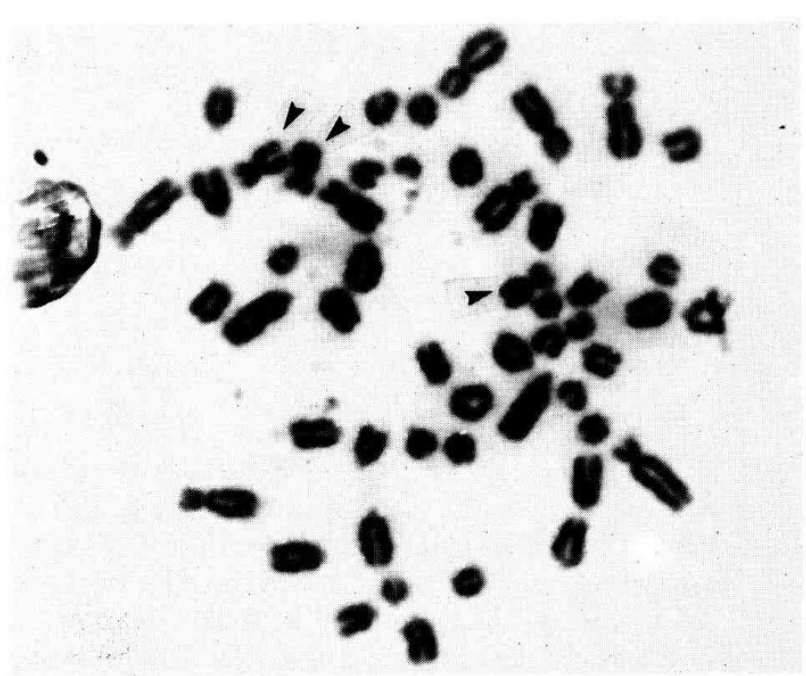

Fig 1. Metaphase showing trisomy of the fifth autosome $(51, \mathrm{XX})$.

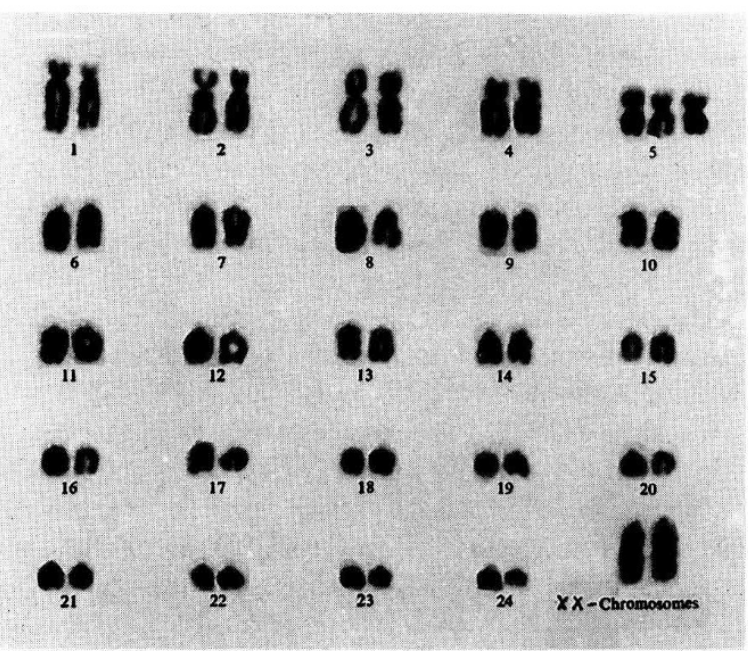

Fig 2. Conventional karyotype showing trisomy of the fifth autosome.

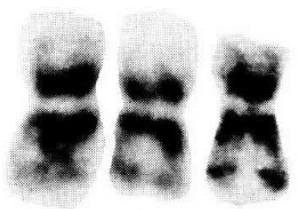

Fig 3. G-banded chromosomes confirming trisomy of the fifth autosome.

arthrogryposis and microphthalmia (Tschudi et al, 1977). Tschudi et al (1977) further described the animal as an intersex. These studies were not conducted in the light of banding patterns and hence could not definitely identify the extra chromo- 


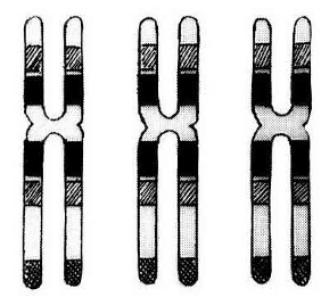

Fig 4. Diagrammatic representation as observed with G-banding.

some. In the report of Dunn and Johnson (1972), the additional chromosome was larger than the other chromosomes indicating some other anomalies accompanied by trisomy. Long (1984) described a 2-day old calf with trisomy of chromosome 21 . The animal was slightly dehydrated and had some dyspnoea. The flexors-tendons of the forelegs were contracted resulting in an inability to stand. A duct from the vestibular gland was enlongated and projected as a fibrous cord from vulval lips. The calf died shortly after examination. Mayr et al (1985) reported a case of trisomy 22 in cattle with a hernia umbilicalis, a urachus fistula and slight brachygnathia inferior. That calf, a female, survived and on maturity became pregnant and gave birth to a normal male calf (Mayr et al, 1987). Makinen et al (1987) reported trisomy-24 in an Ayrshire heifer with slight prognathia inferior, small umbilical hernia and poor growth. The calf died due to unknown cause at the age of 12 months and the only remarkable anomaly detected at autopsy was a thin connective tissue cord at the place of the left uterine tube. The animal was smaller than her contemporaries. Coates et al (1988) found three calves with anomalies of various systems including cardiovascular, respiratory, skeletal, muscular, hepatic and accessory glands. These calves were trisomic, the extra chromosomes being different in each case : 27, an unidentified medium sized, and 21 autosome. Recently Yadav and Basbur (1990) observed a Sahiwal Zebu female calf with crooked legs and trisomy-27.

Dwarfism or growth retardation was reported to be associated with autosomal trisomy (Gluhovschi et al, 1975; Universitate Giessen, 1978; Herzog et al, 1982). In cytogenetical studies on livestock, it is very rare and rather difficult to establish a one-to-one cause and effect relationship. However, from the study of Herzog et al (1982) on 6 calves with the same cytogenetical anomalities and similar phenotypic effect, it appears plausible to implicate trisomy of chromosome 17 with general growth retardation or dwarfism.

In the present investigations, the buffalo was phenotypically normal. Her age at first calving was 46 months, comparable to that of contemporary buffaloes in the herd. The animal did not conceive during two cycles after the 2 nd and 4th month of its first calving. Hence, the ovaries were given massage per rectum. Pregnancy was established during the very next cycle and the buffalo calved normally. Within 3 months the next conception occurred. However, after the third calving at the age of 7 years she became a repeat breeder and did not follow regular oestrous cycles. Rectal tone-up was not helpful. The buffalo was bred unsuccessfully 7 times over a period of one and half years and at that stage the chromosomes were examined. Subsequently, the animal was removed from the herd. 
It was difficult to relate the presence of the abnormal cell line 51,XX to irregular breeding behaviour. Nevertheless, it was evident that the phenotypic effects were different from those reported in trisomic cattle. The reason could be the presence of mosaicism $(50, \mathrm{XX} / 51, \mathrm{XX})$ and lack of trisomy in all the cells. Probably presence of a normal cell line in 67.33 percent of the cells might be the reason for normal phenotype and three calvings. Chromosomes were studied only from blood, and mosaicism at the gonadal level or hormone profile of the animal could not be studied. Furthermore, in our laboratory, 2 buffaloes with breeding problems similar to the present case have been reported earlier. One buffalo had trisomy of the Xchromosome (Yadav and Balakrishnan, 1982) and another, a half-sib of this buffalo, had a pericentric inversion of the fourth chromosome (Balakrishnan et al, 1985).

\section{ACKNOWLEDGMENTS}

The authors are very thankful to Dr WA King for valuable discussions and the Directors of the Institutes for providing the necessary facilities for the present investigations.

\section{REFERENCES}

Balakrishnan CR, Yadav BR, Yadav JS (1985) Spontaneous pericentric inversion in Indian buffalo (Bubalus bubalis). Nucleus 26, 45-48

Bongso TA, Hilmi M (1982) Chromosome banding homologies of a tandem fusion in river, swamp and crossbred buffaloes. Can J Genet Cytol 24, 667-673

Coates JW, Schmutz SM, Rousseaux CG (1988) A survey of malformed aborted bovine fetuses, stillbirths and nonviable neonates for abnormal karyotypes. Can $J$ Vet Res 52, 258-263

Di Berardino D, Iannuzzi L (1981) Chromosome banding homologies in swamp and Murrah buffalo. $J$ Hered $72,183-188$

Di Berardino D, Iannuzzi L, Bettini TM, Matassino D (1981) Ag-NORs variation and banding homologies in two species of Bovidae: Bubalus bubalis and Bos taurus. Can J Genet Cytol 23, 89-90

Dunn HO, Johnson RH Jr (1972) A 61,XY cell line in a calf with extreme brachygnathia. J Dairy Sci 55, 524-526

Gluhovschi N, Bistriceanu M, Palicics R (1975). Reproductive disorders of domestic animals due to changes in genome. Cah Med Vet 44, 155-163

Gupta P, Ray Chaudhuri SP (1978) Robertsonian changes in the chromosomes of Indian Murrah buffalo (Bubalus bubalis). Nucleus 21, 90-97

Herzog A (1974) Autosomal trisomy in lethal brachygnathia of cattle (bovine trisomia-brachygnathia-syndrome). Dtsch Tierarztl Wochenschr 81, 78-80

Herzog A, Hohn H (1968) Autosomale Trisomy bei einem Kalb mit Brachygnathia inferior und Ascites-congenitus. Dtsch Tierarztl Wochenschr 75, 604-606

Herzog A, Hohn H, Olyschlager F (1982) Autosomal trisomy in calves with general underdevelopment (dwarfism). Dtsch Tierarztl Wochenschr 89, 400-403

Long SE (1984) Autosomal trisomy in a calf. Vet Rec 115, 16-17

Makinen A, Alitalo I, Alanko M (1987) Autosomal trisomy in a heifer. Acta Vet Scand 28, 1-8 
Mayr B, Krutzler H, Auer H, Schleger W, Sasshofer K, Glawischnig E (1985) A viable calf with trisomy 22. Cytogenet Cell Genet 39, 77-79

Mayr B, Schellander K, Auer H, Tesarik E, Schleger W, Sasshofer K, Glawischnig E (1987) Offspring of a trisomic cow. Cytogenet Cell Genet 44, 229-230

Miyake YI, Kanagawa H, Ishikawa T (1980) A chromosomal analysis based on the $\mathrm{G}$ and $\mathrm{C}$ band staining techniques of the buffalo (Bubalus bubalis). Jpn J Vet Res $28,122-128$

Mori M, Sasaki M, Makino S, Ishikawa T, Kawata K (1969) Autosomal trisomy in a malformed calf. Proc Jpn Acad 45, 955-959

Seabright M (1971) A rapid banding technique for human chromosome. Lancet ii, 971

Toll GL, Halnan CRE (1976) The Giemsa banding pattern of the Australian swamp buffalo (Bubalus bubalis): chromosome homology with other bovidae. Can J Genet Cytol 18, 303-310

Tschudi P, Uelthschi G, Marting J, Kupper U (1975) Autosomal trisomy as the cause of a defect of the interventricular septum in a Simmental calf. Schweiz Arch Tierh eilkd 117, 335-340

Tschudi P, Zahner B, Kupper U, Stampeli G (1977) Chromosomenuntersuchungen an schweizerischen Rinderrassen. Schweiz Arch Tierh eilkd 119, 329-336

Universitat Giessen (1978) Report of Institute fur Zuchthygiene und Veterinarmedizinische. Giessen, p 17

Yadav BR, Balakrishnan CR (1982) Trisomy of X chromosome in a Murrah buffalo. Vet Rec 111, 184-185

Yadav BR, Balakrishnan CR (1985) Modified medium for lymphocyte culture for chromosome studies in livestock. Indian J Dairy Sci 38, 50-53

Yadav BR, Basrur PK (1990) Autosomal trisomy in Zebu cattle. Can Vet $J$ (in press) 